\title{
Analysis of production factors that affect the productivity of tuna handliners based in Bitung Oceanic Fishing Port
}

\author{
Analisis faktor produksi yang mempengaruhi produktivitas kapal tuna hand line yang \\ berpangkalan di Pelabuhan Perikanan Samudera Bitung \\ Peggy Pontoh, ${ }^{1 *}$ Alfred Luasunaung, ${ }^{2}$ and Emil Reppie ${ }^{2}$ \\ ${ }^{1}$ Program Studi Ilmu Perairan, Program Pascasarjana, Universitas Sam Ratulangi. Jln. Kampus Unsrat Kleak, \\ Manado 95115, Sulawesi Utara, Indonesia. \\ ${ }^{2}$ Fakultas Perikanan dan Ilmu Kelautan, Universitas Sam Ratulangi. Jl. Kampus Unsrat Bahu, Manado 95115 , \\ Sulawesi Utara, Indonesia. \\ *E-mail:peggypontoh@gmail.com
}

\begin{abstract}
Tuna hand lines have been used widely by fishermen in the waters of Sulawesi Sea and Moluccas Sea, to catch big pelagic species with small fishing boats (2-10 GT). Although the gear's design has evolved over centuries, there is still potential for improving its catching efficiency and selectivity. However, the production factors that affect the productivity are still not known. The research aimed to study several production factors that affect the productivity of tuna hand liner based in Bitung Oceanic Fisheries Port; and to determine the most influential production factors on productivity of tuna hand liner. This research was conducted from June to November 2017 in Bitung Oceanic Fishing Port through applying a descriptive method based on case study; and the data were analyzed by using multiple linear regression production function. It was found that production factors that may affect the productivity of the tuna hand liner consist of boat size (GT), engine power (PK), amount of fuel (1), number of crew (person) and number of trips (days). The result of partial analysis shows that the most influential production factor to tuna hand liner productivity is the amount of fuel usage.
\end{abstract}

Keywords: tuna hand line; big pelagic species; production factors; fishing productivity.

Abstrak: Pancing ulur tuna telah digunakan secara luas oleh nelayan di perairan Laut Sulawesi dan laut Maluku, untuk menangkap ikan pelagis besar dengan kapal-kapal ukuran kecil (2 - 10 GT. Walaupun konstruksinya telah berkembang sejak lama, tetapi masih memiliki potensi untuk meningkatkan efisiensi penangkapan dan selektivitasnya. Namun belum diketahui factor-faktor produksi apa saja yang mempengaruhi produktivitasnya. Oleh karena itu, penelitian ini ditujukan untuk mempelajari beberapa factor produksi yang mempengaruhi produktivitas kapal-kapal tuna hand line (THL) yang berpangkalan di Pelabuhan Perikanan Samudera Bitung; dan menentukan factor produksi yang paling berpengaruh terhadap produktivitas kapal THL. Penelitian ini dilakukan pada bulan Juni sampai November 2017 di Pelabuhan Perikanan Samudera Bitung; dikerjakan dengan metode deskriptif yang didasarkan pada study kasus; dan data dianalisis dengan menggunakan fungsi produksi regresi linier berganda. Faktor-faktor produksi yang dapat mempengaruhi produktivitas kapal THL terdiri dari ukuran kapal (GT), kekuatan mesin (PK), jumlah bahan bakar (1), jumlah anak buah kapal (orang) dan jumlah trip (hari). Hasil analisis parsial menunjukan bahwa faktor produksi yang paling berpengaruh terhadap produktivitas kapal THL adalah jumlah penggunaan bahan bakar minyak.

Kata-kata kunci: pancing ulur tuna; ikan pelagis besar; factor-faktor produksi; produktivitas penangkapan.

\section{PENDAHULUAN}

Ikan pelagis besar yang terdapat di perairan Indonesia terdiri dari 11 jenis, yang dikelompokan atas: tuna, cakalang, tongkol, setuhuk (marlin), ikan pedang, tenggiri dan cucut (Uktolseja et al., 1998). Ikan tuna adalah salah satu jenis ikan ekonomis penting di dunia dan merupakan komoditi perikanan terbesar ketiga di Indonesia setelah udang dan ikan dasar. Komoditi ini memiliki harga yang relatif lebih mahal dibandingkan harga jenis ikan lainnya, dimana permintaan pasar terus meningkat. Salah satu penyebab tingginya harga ikan tuna adalah kegemaran orang-orang Jepang menyantap sushi dan sasimi yang terbuat dari daging ikan tuna segar dan menyebar ke negara-negara Eropa dan Timur Tengah (Anonimous, 2011). 
Tabel 1. Spesifikasi pancing tuna hand line (THL)

\begin{tabular}{lllcccc}
\hline No & Bagian & Material & $\begin{array}{c}\text { Ukuran } \\
\text { (Nomor) }\end{array}$ & $\begin{array}{c}\text { Panjang } \\
(\mathrm{m})\end{array}$ & Berat (Kg) & Jumlah \\
\hline 1 & Gulungan tali & Kayu & - & - & $2-3$ & 1 \\
2 & Tali utama & PA Mono & 150 & 400 & - & 1 \\
3 & Tali cabang & PA Mono & 130 & 30 & - & 1 \\
4 & Tali cisabu & PA Mono & 90 & 0,4 & - & 1 \\
5 & Pemberat & Pb & - & - & -2 & 1 \\
6 & Mata pancing & SST & 60 & - & - & 1 \\
7 & Kili - kili & SST & - & - & $3-4$ & 2 \\
8 & Batu & Batu & - & & - & 1 \\
\hline
\end{tabular}

Ikan tuna sebagai salah satu jenis dari kelompok ikan pelagis besar, merupakan suatu kegiatan ekonomi unggulan di sektor perikanan Sulawesi Utara. Namun belum memiliki daya saing yang tinggi dibandingkan dengan Negara Asean lainnya, karena proses produksi belum sepenuhnya efisien. Selain itu, upaya pengembangan kegiatan ekonomi utama perikanan ini, ada beberapa tantangan yang harus dihadapi, antara lain:

- Persaingan di pasar global, dimana beberapa produk perikanan dari negara lain seperti Thailand dan Vietnam memiliki daya saing yang sangat tinggi, dikarenakan proses produksi yang jauh lebih efisien dibandingkan dengan Indonesia.

- Persaingan di pasar dalam negeri, yaitu daerahdaerah lainnya di Indonesia yang memproduksi produk perikanan sejenis.

- Persyaratan kualitas/mutu produk perikanan seperti persyaratan label, kemasan, keamanan produk, traceability, green/eco label dan syarat kandungan BTP akan semakin ketat. Ini merupakan suatu tantangan ke depan agar industri perikanan dapat lebih meningkatkan mutu dan memperketat kontrol kualitas produk perikanan yang dihasilkan.

Salah satu alat tangkap yang umum digunakan oleh nelayan di Sulawesi Utara untuk mengeksplotasi sumberdaya ikan tuna di Laut Sulawesi dan Laut Maluku adalah pancing ulur tuna; karena konstruksinya sederhana, relatif murah dan mudah dioperasikan dengan kapal ukuran kecil $\geq 10$ GT. Namun belum diketahui faktor-faktor produksi apa saja yang mempengaruhi produktivitas kapal-kapal THL yang berpangkalan di Pelabuhan Perikanan Samudera Bitung (PPS Bitung).

Penelitian ini bertujuan untuk mempelajari beberapa faktor produksi yang mempengaruhi produktivitas kapal-kapal THL yang berpangkalan di Pelabuhan Perikanan Samudera Bitung, dan menentukan factor produksi yang paling berpengaruh terhadap produktivitas kapal tuna hand line (THL).

\section{MATERIAL DAN METODA}

\section{Bahan dan Alat Penelitian}

Bahan dan alat yang digunakan dalam penelitian terdiri dari laporan tahunan perikanan THL di Pelabuhan Perikanan Samudera Bitung, kamera, meteran, komputer dan alat tulis menulis.

\section{Metode Penelitian}

Penelitian ini dikerjakan dengan metode deskriptif yang didasarkan pada studi kasus (Nazir, 1999). Data primer dikumpulkan melalui wawancara, pengisian daftar pertanyaan, dan pengukuran langsung; sedangkan data sekunder dilakukan dengan mencatat atau mengutip informasi yang tersedia di Pelabuhan Perikanan Samudera Bitung dan instansi terkait, serta telaah pustaka yang relevan. Jumlah sampel yang dipilih adalah 10 unit kapal THL yang terdapat dilokasi penelitian

Informasi yang diperlukan berupa faktorfaktor produksi kapal THL yang terdiri dari ukuran kapal (GT), kekuatan mesin (PK), jumlah bahan bakar (1), jumlah anak buah kapal (orang), jumlah trip (hari) dan dan hasil tangkapan masing-masing kapal.

\section{Analisis Data}

Dalam penelitian ini, hubungan antara produksi ikan hasil tangkapan dengan peralatan dan sarana penunjangnya disebut sebagai suatu fungsi produksi. Hubungan antara faktor-faktor produksi dapat diketahui dengan menggunakan fungsi produksi regresi linier berganda dengan formula sebagai berikut (Hasan, 2003): 


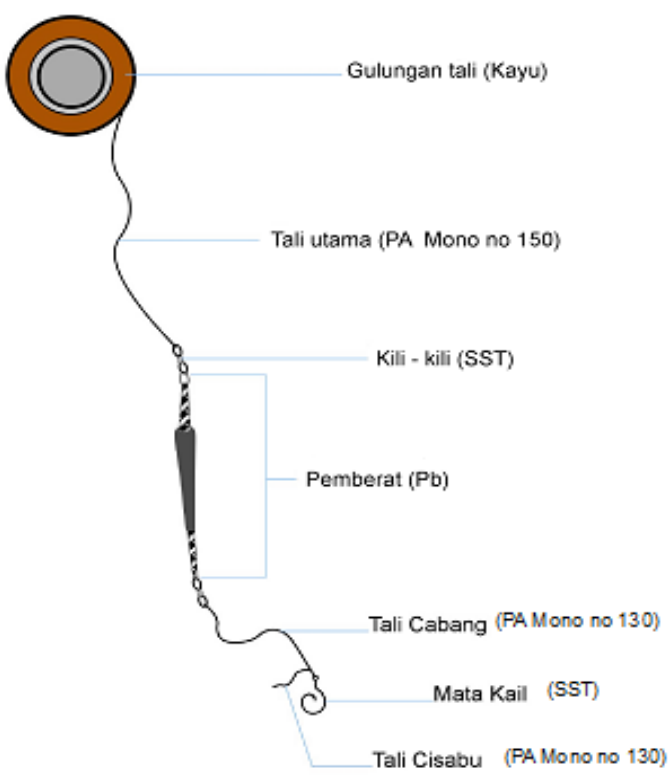

Gambar 2. Pancing tuna hand line

$\mathrm{Y}=\mathrm{bo}+\mathrm{b} 1 \mathrm{X} 1+\mathrm{b} 2 \mathrm{X} 2+\mathrm{b} 3 \mathrm{X} 3+\ldots+\mathrm{bn} \mathrm{Xn}+\mathrm{e}$ di mana:

Y : dugaan produksi hasil tangkapan

Bo : intersep

b1 : koefisien regresi

$\mathrm{X} 1-\mathrm{Xn}$ : faktor-faktor produksi yang digunakan e : galat

Model regresi berganda merupakan model regresi dengan dua atau lebih variabel bebas. Analisis regresi berganda merupakan suatu analisis bersyarat terhadap nilai-nilai tetap dari variabel-

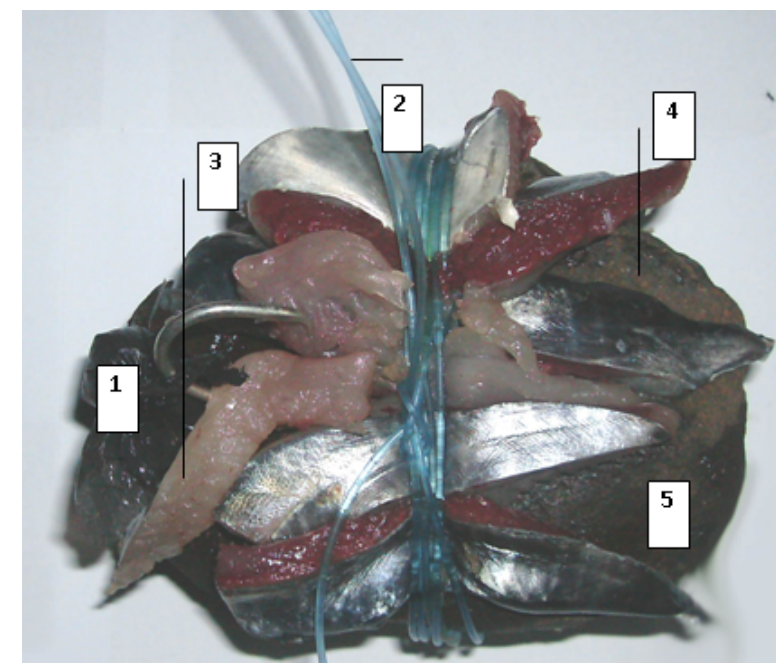

Keterangan:

1. Larutan cisabu; 2. Tali cabang pancing;

3. Mata pancing; 4. Umpan; 5. Batu

Gambar 4. Cara mengikat umpan pada batu

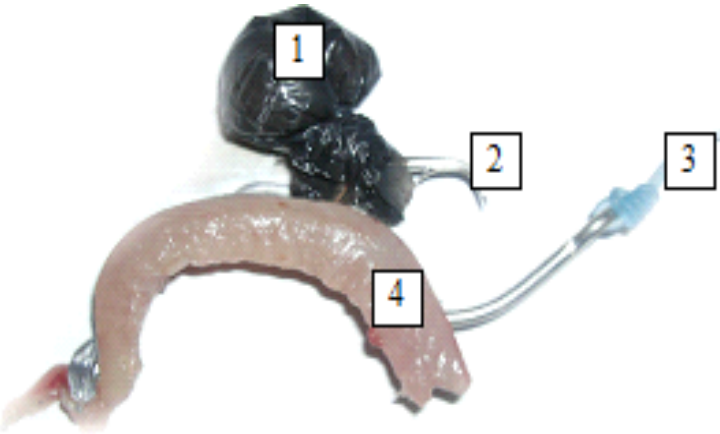

Keterangan:

1. Larutan cisabu

2. Mata pancing

3. Tali cabang pancing

4. Umpan

Gambar 3. Letak umpan dan kantong cisabu pada mata pancing

variabel bebas. Dengan demikian, akan diperoleh nilai rata-rata dari $Y$ untuk setiap nilai dari variabel $\mathrm{X}$.

Untuk mengetahui hubungan atau korelasi antara nilai-nilai $\mathrm{X}$ dan $\mathrm{Y}$ adalah sebagai berikut (Walpole, 1995; Walpole and Myers, 1995):

- Apabila nilai $r$ (determinasi) mendekati nilai positif satu (+1) atau negatif satu (-1), hubungan linier antara X dan Y kuat dan terdapat korelasi yang tinggi antara kedua variabel tersebut.

- Apabila nilai $r$ (determinasi) mendekati nol, hubungan linier antara $\mathrm{X}$ dan $\mathrm{Y}$ sangat lemah atau tidak ada sama sekali.

Faktor-faktor produksi yang dianalisis dan dianggap sebagai variabel penentu produksi hasil tangkapan meliputi:

- Variabel tidak bebas (Y) adalah: hasil tangkapan THL, yang diperoleh dalam 6 bulan, dengan satuan ukurannya adalah $\mathrm{kg} /$ trip

- (2) Variabel bebas (X) adalah: 1). ukuran kapal (GT); 2). kekuatan mesin (PK); 3). jumlah bahan bakar (liter/trip); 4). Jumlah ABK (orang) dan 5). jumlah trip (hari)

Pengujian untuk mengetahui hubungan keeratan antara produksi dan ke-5 faktor produksi berdasarkan nilai koefisien korelasi dilakukan dengan menggunakan analisis regresi linear berganda. Sedangkan untuk mengetahui apakah ada pengaruh dari ke-5 (X1-5) faktor produksi terhadap produksi $(\mathrm{Y})$ dilakukan dengan uji $\mathrm{F}$, dan untuk mengetahui faktor produksi yang berpengaruh langsung dan tidak langsung dari dilakukan dengan uji t. 
Journal of Aquatic Science \& Management, Vol. 7, No. 1 (April 2019)

Tabel 2. Fungsi produksi kapal tuna hand line di PPS Bitung

\begin{tabular}{|c|c|c|c|c|c|c|}
\hline No & $\begin{array}{c}\text { Ukuran } \\
\text { kapal (GT) } \\
\text { X1 } \\
\end{array}$ & $\begin{array}{c}\text { Kekuatan } \\
\text { Mesin }(\mathrm{PK}) \\
\text { X2 }\end{array}$ & $\begin{array}{c}\text { Jumlah } \\
\text { BBM (1) } \\
\text { X3 }\end{array}$ & $\begin{array}{c}\text { Jumlah } \\
\text { ABK (org) } \\
\text { X4 } \\
\end{array}$ & $\begin{array}{c}\text { Jumlah } \\
\text { trip (hari) } \\
\text { X5 } \\
\end{array}$ & $\begin{array}{c}\text { Produksi } \\
\text { (kg/trip) } \\
\mathrm{Y}\end{array}$ \\
\hline 1 & 6 & 60 & 9395 & 6 & 173 & 9975 \\
\hline 2 & 2 & 65 & 6275 & 9 & 138 & 12465 \\
\hline 3 & 10 & 75 & 2335 & 6 & 99 & 2455 \\
\hline 4 & 6 & 70 & 3260 & 4 & 170 & 11586 \\
\hline 5 & 4 & 85 & 12330 & 6 & 123 & 18794 \\
\hline 6 & 4 & 80 & 4910 & 6 & 132 & 17310 \\
\hline 7 & 6 & 60 & 4130 & 5 & 144 & 18268 \\
\hline 8 & 8 & 100 & 17820 & 7 & 114 & 10455 \\
\hline 9 & 6 & 125 & 11665 & 6 & 142 & 3475 \\
\hline 10 & 6 & 105 & 18135 & 6 & 171 & 4379 \\
\hline$\sum$ & 58 & 825 & 90255 & 61 & 1406 & 109162 \\
\hline Rataan & 5,8 & 82,5 & 9025,5 & 6,1 & 140,6 & 10916,2 \\
\hline
\end{tabular}

Pengujian yang dilakukan terhadap hubungan faktor-faktor yang memengaruhi produksi sebagai berikut :

1) Pengujian pengaruh bersama faktor produksi yang digunakan terhadap produksi (Y) dilakukan dengan uji statistik F, Yaitu :

Ho: $\mathrm{b} 1=0$ (antara $\mathrm{Y}$ dengan $\mathrm{Xi}$ tidak ada hubungan)

$\mathrm{H} 1: \mathrm{b} 1 \neq \mathrm{c} 0$ (Y tergantung terhadap $\mathrm{Xi}$ secara bersama-sama)

2) Pengujian pengaruh masing-masing faktor teknis produksi dilakukan dengan uji t student, yaitu :

Ho: $\mathrm{b} 1=0$ (antar $\mathrm{Y}$ dengan $\mathrm{X}$ tidak ada hubungan)

$\mathrm{H} 1:$ b1 $\neq 0$ (antara $\mathrm{Y}$ dengan $\mathrm{X}$ terdapat hubungan)

Pengolahan data dilakukan dengan program SPSS 16.0 menggunakan selang kepercayaan $\alpha=$ 0,05 .

\section{HASIL DAN PEMBAHASAN}

\section{a. Unit Penangkapan Tuna Hand Line (THL)}

\section{- Kapal Penangkap}

Kapal THL yang berpangkalan di Pelabuhan Perikanan Samudera Bitung yang dijadikan sampel terbuat dari kayu (gopasa dan kapuraca) dan laminating fiberglass; dengan panjang berkisar 14 $17,5 \mathrm{~m}$, lebar 3,30 - 4,25 $\mathrm{m}$ dan tinggi 1,2 - 1,8 m. Besar kapal antara 2 - 10 GT; dengan mesin dalam merek Yamaha, Mitsubishi dan Isuzu berkekuatan antara 40 - 160 PK. Alat bantu dalam operasi penangkapan adalah perahu tipe pakura sebanya 4 6 buah.

\section{- Alat Tangkap}

Pancing ulur tuna atau THL secara umum terdiri dari bagian-bagian: gulungan tali, tali utama, tali penghantar atau tali cabang, pemberat, mata pancing, dan batu; spesifikasinya disajikan pada Tabel 1 dan Gambar 2.

\section{- Teknik Pengoperasian Alat tangkap}

Tenaga kerja pada setiap kapal THL berkisar antara 4 - 8 orang, yaitu satu orang fishing master. Satu orang juru mesin dan 4 - 6 orang pemancing. Setibanya di daerah penangkapan, nelayan terlebih dahulu menangkap ikan-ikan kecil untuk dijadikan umpan, seperti tongkol (Auxis tsard), cakalang (Katsuwonus pelamis) dan tuna kecil (Thunnus sp.), menggunakan pancing bira-bira (vertical hand line). Ikan umpan disayat-sayat: dan salah satu sayatan dikaitkan pada mata pancing (Gambar 3). Mata pancing yang telah berumpan, digabung dengan beberapa sayatan umpan lepas dan kantong cairan cisabu (squid liver oil) diikat secara khusus pada batu; menggunakan tali cabang pancing; kemudian ujung tali cisabu ditusukan pada kantong yang berisikan cisabu (Gambar 4). Tali pancing kemudian diturunkan pada kedalaman 50 -150 m. Apabila tali pancing sudah terasa tegang, maka tali utama disentak sekuat mungkin sehingga ikatan tali cabang pada batu terlepas, dan sayatan umpan lepas yang diikatkan pada batu berhamburan dalam air, bersamaan dengan menyebarnya larutan cisabu. Hal ini diharapkan menarik perhatian ikan target. untuk memakan sayatan umpan termasuk yang umpan yang dikaitkan pada mata pancing. Tali pancing kemudian ditarik dengan hati-hati sampai ikan hasil tangkapan mendekati perahu. Ikan tersebut dipukul dengan sepotong kayu pada pangkal kepala, sebelum dinaikkan dengan ganco ke atas perahu. 
Pontoh et al.: Analysis of production factors that affect the productivity of tuna handliners based in Bitung ...

Tabel 3. Hasil analisis parsial faktor produksi Tuna Handline yang dioperasikan di PPS Bitung dengan menggunakan uji t student

\begin{tabular}{crrr}
\hline Faktor Produksi & Koefisien & Standar Deviasi & $\begin{array}{c}\mathrm{t}_{\text {hitung }} \\
(\mathrm{db}=14)\end{array}$ \\
\hline Konstanta & 90122.894 & 14480.648 & 6.224 \\
Ukuran Kapal $\left(\mathrm{x}_{1}\right)$ & -2820.829 & 528.249 & -5.340 \\
Daya Mesin $\left(\mathrm{x}_{2}\right)$ & -223.312 & 60.295 & -3.704 \\
Jumlah BBM $\left(\mathrm{x}_{3}\right)$ & 0,658 & 0,240 & $2.742 *$ \\
Jumlah ABK $\left(\mathrm{x}_{4}\right)$ & -3935.273 & 985.648 & -3.993 \\
Jumlah Trip $\left(\mathrm{x}_{5}\right)$ & -187.463 & 48.152 & -3.893 \\
\hline
\end{tabular}

Keterangan: $\mathrm{t}$ tabel $(0,05)=2,262 ; *$ = nyata pada selang kepercayaan $95 \%$

Jenis-jenis ikan yang dominan tertangkap adalah tuna sirip kuning (Thunus albacores).

\section{b. Fungsi Produksi}

Fungsi produksi dari 10 unit kapal THL tahun 2017 yang diteliti di Pelabuhan Perikanan Samudera Bitung disajikan dalam Tabel 2.

\section{- Koefisien Determinasi (R2)}

Koefisien determinasi digunakan untuk mengetahui besar pengaruh nilai variabel independent $(\mathrm{Xi})$ terhadap nilai variabel dependent (Y) dan dapat diketahui dengan melihat dari nilai koefisien determinasi (R2). Hasil perhitungan R2 dengan menggunakan SPSS versi 16.0 dengan menghasilkan output yang dapat dilihat pada Tabel 3 .

Pada output model summary terdapat nilai koefisien determinasi sebesar 0,915 atau 91,5\% dari koefisien korelasi sebesar 95,8\%. Dengan nilai koefisien determinasi (R2) menunjukan bahwa presentase pengaruh variabel independent yang digunakan dalam model sebesar 95,8\% variabel dependent, dan sisanya $4,2 \%$ dipengaruhi oleh variabel lain yang tidak dimasukkan dalam model penelitian ini. Faktor-faktor lain tersebut misalnya faktor lingkungan atau kondisi daerah penangkapan seperti cuaca, musim penangkapan dan keadaan sumberdaya.

\section{- Uji F}

Uji $\mathrm{F}$ digunakan untuk mengetahui apakah variabel independent (Xi) secara bersama-sama berpengaruh secara signifikan terhadap variabel dependent (Y). Hasil analisis secara bersama-sama dengan menggunakan uji $\mathrm{F}$, diperoleh nilai $\mathrm{Fhit}=$ 8,616 lebih besar dari nilai $\mathrm{Ftab}=0,029 \mathrm{a}$. Hal ini menunjukkan, bahwa semua faktor produksi memberikan pengaruh nyata terhadap produksi hasil tangkapan THL pada tingkat kepercayaan 95\%. Pengaruh yang diberikan oleh faktor-faktor produksi tersebut bersifat langsung dan tidak langsung terhadap produksi.

Untuk menguji pengaruh secara langsung dan tidak langsung dari masing-masing faktor produksi yang berpengaruh terhadap produksi hasil tangkapan THL, dilakukan dengan uji t. Berdasarkan hasil pengujian secara parsial memperlihatkan, bahwa hanya Jumlah BBM (X3) dan Jumlah trip (X5) yang memberikan pengaruh nyata secara langsung terhadap produksi THL pada tingkat kepercayaan 95\%. Hal ini berarti, bahwa penambahan kedua faktor produksi tersebut dapat meningkatkan produksi dan demikian pula sebaliknya; jika dilakukan pengurangan nilai ukuran terhadap ketiga faktor ini akan mengurangi produksi THL. Faktor produksi seperti Ukuran Kapal (X1), Kekuatan Mesin (X2), jumlah ABK (X4), dan Jumlah Trip (X5) tidak berpengaruh secara langsung terhadap produksi THL, karena nilai thitung yang diperoleh lebih kecil daripada nilai ttabel pada tingkat kepercayaan $95 \%$.

Ukuran kapal tidak memberikan pengaruh langsung terhadap produksi THL. Faktor ukuran kapal berpengaruh terhadap ukuran kekuatan mesin yang digunakan, stabilitas kapal, dan kemampuan kapal dalam menampung hasil tangkapan dalam palka. Mesin yang berkekuatan besar, umumnya, menggunakan kapal yang juga berukuran besar. Ukuran mesin yang digunakan ini yang tidak berpengaruh langsung terhadap produksi THL, karena setelah sampai di fishing ground mesin kapal di matikan pada saat operasi penangkapan ikan. Kapal yang berukuran besar juga mampu menampung hasil tangkapan yang banyak; namun, hasil tangkapan yang diperoleh bergantung pada produktivitas alat tangkap dan kondisi sumber daya.

Hasil analisis juga menunjukkan, bahwa kebutuhan BBM memberikan pengaruh langsung terhadap produksi. Hubungan antara faktor input yang berpengaruh langsung terhadap produksi THL yang beroperasi di WPP 716 dan WPP 715 . 
Berdasarkan hasil analisis regresi linier berganda, maka formula fungsi produksi THL di PPS Bitung dapat dirumuskan sebagai berikut:

$\mathrm{Y}=90122,894-2820,829 x 1-223,312 \times 2+0,658 \times 3$ - 3935,273x4 - 187,463x5

Nilai intersep yang diperoleh berdasarkan persamaan di atas adalah sebesar 90122,894, yang menunjukkan, bahwa titik potong garis regresi terletak pada sumbu Y positif. Nilai koefisien untuk daya muat kapal, daya mesin, Jumlah ABK, serta jumlah trip adalah negatif. Hal ini dapat diartikan, bahwa penambahan seluruh faktor input tersebut akan menurunkan produksi THL; demikian pula sebaliknya, jika dilakukan pengu-rangan terhadap faktor input ini akan meningkatkan hasil tangkapan THL. Khusus bagi Jumlah BBM, koefisien yang diperoleh bernilai positif; artinya, bahwa penambahan jumlah BBM akan meningkatkan produksi dan sebaliknya jika dilakukan pengurangan jumlah BBM akan menurunkan produksi THL.

\section{KESIMPULAN}

1. Faktor-faktor produksi yang dapat mempengaruhi produktivitas kapal THL terdiri dari ukuran kapal (GT), kekuatan mesin (PK), jumlah bahan bakar (1), jumlah anak buah kapal (orang) dan jumlah trip (hari).
2. Faktor produksi yang paling berpengaruh terhadap produktivitas kapal THL adalah jumlah penggunaan bahan bakar minyak.

\section{REFERENSI}

ANONIMOUS (2011) Panduan Pengoperasian Tuna Long Line Ramah Lingkungan Untuk mengurangi hasil tangkapan sampingan (by cath). World Wildlife Fun.

HASAN, M.I. (2003) Pokok-Pokok Materi Statistik 2 (Statistik Inferensif). Jakarta: Bumi Aksara.

NASIR, M. (1999) Metode Penelitian. Cetakan Keempat. Jakarta: Ghalia Indonesia. 597 hal.

UKTOLSEJA, J.C.B., PURWASASMITA, R., SUSANTO, K. and SULISTIADJI, A.B. (1998) Sumberdaya ikan pelagis besar. In: Potensi dan penyebaran sumberdaya ikan laut di perairan Indonesia. Komisi Nasional Pengkajian stok sumberdaya ikan laut, p. 4088.

WALPOLE, R.E. (1995) Pengantar Statistika. Edisi ke-3. Jakarta: PT.Gramedia Pustaka Utama.

WALPOLE, R.E. and MYERS, R.H. (1995) Ilmu Peluang dan Statistik untuk Insiyur dan Ilmuwan. Edisi ke-4. Bandung: Penerbit ITB.

Received: 15 January 2019 Accepted: 30 March 2019 